\title{
The Evaluation of Digital Brand Storytelling Implementation in Local Brand
}

\author{
Fairuz Nisa Fauziah and Ira Fachira
}

\section{ABSTRACT}

\begin{abstract}
In the digital era, where there are so many choices of brands, each brand must have good communication skills with its audience. One strategy that is now widely applied in various brands is the brand storytelling technique. Telling stories on social media is not just writing or just uploading content but must interact with the audience. Now, every brand must survive with good customer engagement with its consumers to be sustainable. Every brand certainly has a meaningful story that is shared with its audience through various strategies. Therefore, every brand must recognize and evaluate the brand storytelling strategy that has been implemented. Through brand storytelling, consumers will become part of the brand and engage for a long time. Implementation of brand storytelling needs to pay attention to the performance of the content marketing and how to arrange the elements of the signature stories in the strategy. The result of this study are solutions that can be applied to strengthen brand storytelling on Sewderhana Goods.
\end{abstract}

Keywords: Brand Story, Storytelling, Digital Era, Customer Engagement.

\section{INTRODUCTION}

\section{A. Background}

The trend towards local brands and products continues to grow, and new brands emerge every day. Although there are many international brands and products, various local products can show promising growth through competitive quality and prices and good marketing and branding strategies [1].

The rise of local products has become a new phenomenon in recent years, especially in Indonesia. This phenomenon is also marked by the millennial generation, who are proud to use local products. Every brand must communicate its brand value to the audience. Many local brands are trying to implement a brand storytelling strategy for their promotion strategy. Implementing the right brand communication strategy in the digital marketing era is essential to get consumers' attention and heart.

Digital Storytelling techniques can be applied through social media, video marketing, and content marketing. These channels are used to let consumers know that a particular product or service exists and communicate stories that drive long-term customer engagement.

Today, businesses need to learn how to integrate storytelling into their marketing and communications efforts to make their brands appear more appealing and captivating. Every brand has a story and value to tell to the audience. Every brand has a brand story, which is the narrative behind a brand, created to strengthen the brand identity with creative,
Submitted : August 03, 2021

Published : August 25, 2021

ISSN: $2507-1076$

DOI: $10.24018 /$ ejbmr.2021.6.4.1030

F.airuz Nisa Fauziah*

Bandung Institute of Technology, Bandung, West Java, Indonesia.

(e-mail: fairuz_nisa@sbm-itb.ac.id) Ira Fachira

Bandung Institute of Technology, Bandung, West Java, Indonesia.

(e-mail: ira@sbm-itb.ac.id)

*Corresponding Author authentic, and engaging elements [5].

Understanding the elements of a brand story can help businesses design good brand stories and increase consumer engagement and consumer trust in the brand [2].

Thus, it is necessary to study the storytelling strategy in this digital era to strengthen marketing and communication efforts, especially to promote a brand.

\section{B. Business Overview}

This study will compare digital brand storytelling to several local brands in Indonesia, such as Sewderhana Goods, Lepas Wear, and the Sehari Selembar Kain brand. These three brands are included in the creative fashion industry, such as:

- Sewderhana Goods is a local brand that provides everyday products through fabrics that tell simple things and relate to daily stories. Sewderhana Goods is present in early 2019, which is located in Bandung, West Java, Indonesia. Sewderhana Goods products include tote bags, shopping bags, the production of bags/pouches, calendars, and other daily necessities for a sustainable life and raise a minimalist lifestyle.

- Lepas Wear is a local brand from Bandung, Indonesia, since early 2019 with products in daily clothes made of natural linen. The Lepas Wear strategy focuses on the consumer experience when using the product, namely by inviting consumers to feel natural fabrics. Each product has a name and a story. So is the story behind the presence of the product so that there is an emotional bond. Consumers' feelings are invited to be immersed in 
the stories presented by Lepas Wear. They prioritize the concept of sustainable wear by consistently using environmentally friendly materials in each of their products. Uniquely, Lepas Wear does not just sell clothes; the audiences will fall in love with every story the social media content tells. Stories about letting go or "Lepas" remind consumers of the essence of the minimalist lifestyle.

- Sehari Selembar Kain, A local brand from Surabaya, Indonesia, since 2019, has a signature hand-illustrated scarf. The scarves are made exclusively with abstract and geometric illustrations that have a touching story. Offering cloth for the veil but all female friends (not only Muslim women). They want to convey a message in every piece. They are inspired by nature and everyday stories for female friends. Whoever wears Sehari Selembar Kain scarf wants to treat them as a friend.

\section{Research Objective}

This research aims to determine the digital brand storytelling implementation in local brands and proposed solutions for Sewderhana Goods improvement or other local brands.

\section{LITERATURE REVIEW}

\section{A. Brand Storytelling}

Before understanding brand storytelling, it is necessary first to understand the definition of a brand. A brand is the number of interactions, both actual and perceived, between audience and company through its platform or channel [3]. Storytelling is one of the brand communication tools in which there is a brand story to clarify brand value to consumers [4].

Brand storytelling is not about creating marketing campaigns or creating content on social media. However, Brand storytelling is a process of shaping the business's identity with narratives and storytelling techniques that can connect with the business's values by building meaningful connections [3].

\section{B. Brand Story}

Every brand has a story to tell its audience. Have a conflict or meaningful story behind the presence of the brand. Stories can come from various things or reasons, for example, from several places, which may be the company's values or how people enjoy the products or services [3]. In terms of objectives, there are two, namely strategic brand stories and tactical brand stories.

\section{a) Strategic Brand Story}

The strategic brand story will focus on the brand story that can be seen from the vision or value conveyed by the brand [4]. An impactful signature brand story must have intriguing, authentic, and involving elements [5]. The following are the signature stories:

1) A story. A signature brand story is just that - a narrative with a beginning, middle, and end (a resolution).

2) Intriguing. An intriguing story is "thought-provoking, novel, informative, interesting, or entertaining.

3) Authentic. The characters, settings, and challenges must feel natural.
4) Involving: Get people involved and want to share stories.

5) Surprise: the moment that some in the audience will be motivated to talk about and share.

6) A visual image: Visualizing aspects of the story improves memory and impact and create content that better describes the story.

7) A meaningful challenge or obstacle-The challenge should be actual or based on facts, and the story hero should overcome it.

8) Empathic character emerges in a story, empathic story character that will stimulate the same emotions that the character experiences.

9) Conflict and tension. Create an emotional involvement.

10) Details: important details enhance the authenticity of the story.

b) Tactical Brand Story

In contrast to strategic stories, tactical stories told through advertisements, brand promotion videos, websites, and other means of communication are more dynamic and are used for short-term communication [4]. Tactical stories are designed to achieve the organization's short-term communication goals based on the company's values or organization [6].

\section{Customer Engagement}

Engagement rate is a metric used to assess the average number of brand interactions such as likes, comment, saves on social media content receives per follower. Below is an industry-standard guideline [7]:

- Less than $1 \%$ = low engagement rate;

- Between $1 \%$ and $3.5 \%=$ average/good engagement rate;

- Between $3.5 \%$ and $6 \%=$ high engagement rate;

- Above $6 \%=$ very high engagement rate.

$$
\text { Average ER }=\frac{\text { Toral Reaction of post }(\text { Likes }+ \text { Comments })}{\text { Count of post } \times \text { flowers }} \times 100 \%
$$

\section{RESEARCH METHODOLOGY}

This study uses a mixed-method, namely qualitative and quantitative data, as an analysis process. Mixed methods research is a group of approaches to conducting research studies that combine quantitative and qualitative that involve collecting, analyzing, and integrating quantitative and qualitative research into one study so that the results can be more comprehensive [8]. The data collection in this study is as follows:

(1) Primary Data: internal data (content marketing performance) and observation.

(2) Secondary Data: benchmarking, literature review, and internet research.

The analysis process carried out in this study is benchmarking. Benchmarking Compares the company's products and processes to competitors or leading firms in other industries to identify best practices and find ways to improve quality and performance [9].

Benchmarking is one of the tools that companies or 
organizations usually use to evaluate products or services for improvement. In practice, it will analyze other companies with best practices in certain aspects that have best practices to get an overview of improvements within the same organization or company, among firms competing in the same industry, or between a company with processes in various industries [10].

In the benchmarking process, these brands are based on similarities in their storytelling techniques, namely telling about everyday life using a narrative writing style on Instagram that is warm and has the same consumer character. These brands are different (non-competitors) in terms of products, but they are still one industry, namely the fashion industry. Based on the type of object, it is a type of functional performance benchmarking, namely observing and comparing the functionality process of competitors in the same industry even though they are not competitors [11].

\section{FINDING AND DISCUSSION}

\section{A. Strategic Brand Story}

The following is the implementation of the element signature stories of Sewderhana Goods and Lepas Wear.

Here is a glimpse of the application of the signature story element on Sewderhana Good, Lepas Wear, and Sehari Selembar Kain Brand to see the overall visualization of brand identity in the application of story signature elements.

Of all the content published on Instagram, Sewderhana Goods, Lepas Wear, and Sehari Selembar Kain display their products with various characters and activities. The brand story aligns with their products.

Lepas Wear applies brand story elements well in every storytelling component on their Instagram social media, especially on authentic, involving, and empathetic story character elements.
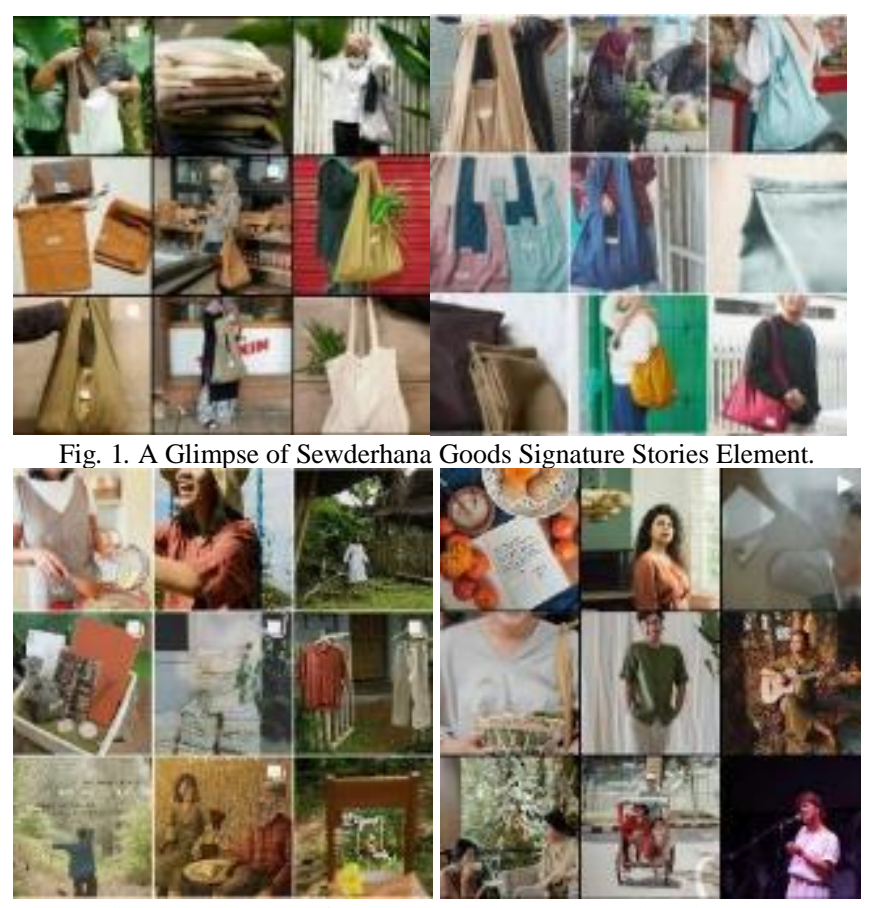

Fig. 2. A Glimpse of Lepas Wear Signature Stories Element.

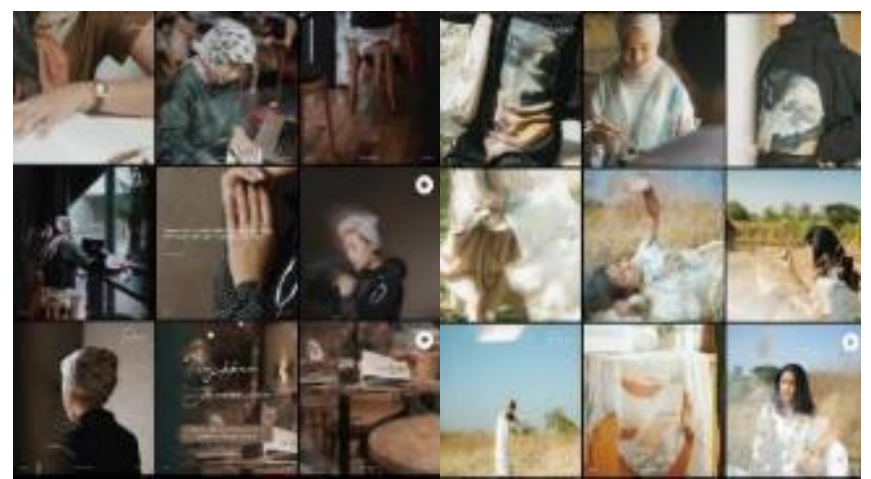

Fig. 3. A Glimpse of Sehari Selembar Kain Signature Stories Element.

TABLE I: EVALUATION OF SignATURE STORIES ElEMENT

\begin{tabular}{|c|c|c|c|}
\hline $\begin{array}{c}\text { Element of } \\
\text { Signature Stories }\end{array}$ & Sewderhana Goods & Lepas Wear & Sehari Selembar Kain \\
\hline A brand story & $\begin{array}{l}\text { Enjoy simple things in everyday life } \\
\text { through cloth/ fabric }\end{array}$ & $\begin{array}{l}\text { A message about letting go through the } \\
\text { friendliness of the clothes. }\end{array}$ & $\begin{array}{l}\text { Sending messages from every piece of fabric } \\
\text { for all women }\end{array}$ \\
\hline Tagline & $\begin{array}{c}\text { "Yang sederhana yang mungkin bisa } \\
\text { menyempurnakan" }\end{array}$ & "Melepaskan adalah seni kehidupan" & $\begin{array}{l}\text { "Terinspirasi dari keseharian, dituangkan } \\
\text { dalam selembar kain" }\end{array}$ \\
\hline Intriguing & Entertaining and Interesting content & $\begin{array}{l}\text { Entertaining, interesting, and } \\
\text { informative content }\end{array}$ & Entertaining, interesting, informative content \\
\hline \multirow[t]{3}{*}{ Authentic } & $\begin{array}{l}\text { - Setting: street, market, stores, } \\
\text { traditional market, supermarket, }\end{array}$ & $\begin{array}{l}\text { - Setting: house, street, traditional } \\
\text { market, public spaces }\end{array}$ & $\begin{array}{l}\text { - Setting: house, street, public spaces } \\
\text { nature, foreign country }\end{array}$ \\
\hline & $\begin{array}{c}\text { public spaces } \\
\text { - Content: using personal, consumer, }\end{array}$ & $\begin{array}{c}\text { - Content: using personal, consumer, or } \\
\text { influencer shots. }\end{array}$ & $\begin{array}{c}\text { - Content: using personal, consumer, or } \\
\text { influencer shots }\end{array}$ \\
\hline & $\begin{array}{l}\text { or influencer shots. } \\
\text { - Character: influencer, consumer, } \\
\text { and founder's relatives }\end{array}$ & $\begin{array}{l}\text { - Character: influence, consumer, } \\
\text { founder relatives, and the founder }\end{array}$ & - Character: influencer, consumer \\
\hline Involving & $\begin{array}{l}\text { Involving consumer and public } \\
\text { figures in occasionally }\end{array}$ & $\begin{array}{l}\text { involve consumers and public figures, } \\
\text { even the founder in the product story }\end{array}$ & involve consumers and public figures \\
\hline $\begin{array}{l}\text { Empathetic story } \\
\text { character }\end{array}$ & Dominated by product & $\begin{array}{l}\text { Inspiring character in each product } \\
\text { series }\end{array}$ & $\begin{array}{c}\text { Consumer character align with each product } \\
\text { series }\end{array}$ \\
\hline $\begin{array}{l}\text { Conflict and } \\
\text { tension }\end{array}$ & $\begin{array}{l}\text { Challenge for the society for a 'less } \\
\text { plastic' living }\end{array}$ & $\begin{array}{l}\text { Worries from the fear of missing out } \\
\text { "fomo." }\end{array}$ & Not all women know how to wear a scarf \\
\hline $\begin{array}{l}\text { Meaningful } \\
\text { challenge }\end{array}$ & $\begin{array}{l}\text { Provide products for people who are } \\
\text { just learning to reduce single-use } \\
\text { plastic }\end{array}$ & Creates sustainable fashion & $\begin{array}{l}\text { Creating scarf that all women can wear } \\
\text { (not only for Muslim women) }\end{array}$ \\
\hline Detail & Focus on product visualization & Visualization based on experience & audience's stories through visualization \\
\hline Surprise & $\begin{array}{l}\text { The customer does not expect the } \\
\text { products will have scents }\end{array}$ & $\begin{array}{c}\text { The founder exclusively wrote greeting } \\
\text { cards }\end{array}$ & $\begin{array}{l}\text { Every piece of fabric has meanings from } \\
\text { behind the illustration }\end{array}$ \\
\hline
\end{tabular}




\section{B. Tactical Brand Story}

In this benchmarking analysis, we will discuss the conditions of applying tactical brand stories as a strategy to promote the brand to the audience.

Based on the benchmarking above, from a tactical brand story strategy, the form of communication promotion for Sewderhana Goods is not as varied as other brands. In addition, Sewderhana still does not regularly promote its brand stories compared to the other three brands. Lepas Wear has the most well-planned promotional strategy through storytelling because it has the most complete and consistent promotional mix in its implementation. Lepas Wear involves various characters in their product promotion, including the founder, who can share stories in every promotion. Likewise, the Sehari Selembar Kain brand consistently displays the figure in each product series. Lepas Wear dan Sehari Selembar Kain shows a figure for a photo catalog and introduces their personality to the audience.

Based on the event aspect, Lepas Wear managed to utilize momentum in developing its branding strategy. Its activities are also related to its brand value with the theme of selfhealing. The tactical brand story in Lepas Wear is consistent in its promotion and can maintain and take advantage of the most challenging conditions. As proof, Lepas Wear can still maintain its promotional strategy during the COVID-19 Pandemic with various online events and collaborations.

The following is the brand tactical strategy in these local brands:

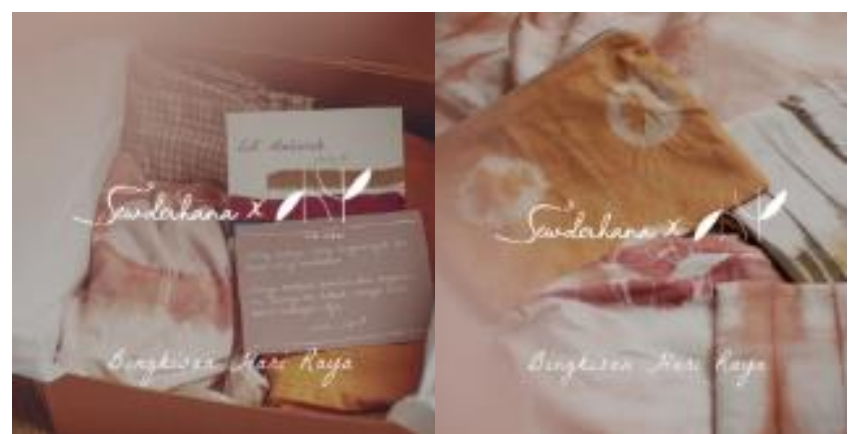

Fig. 4. Sewderhana Goods Brand Collaboration in 2020.

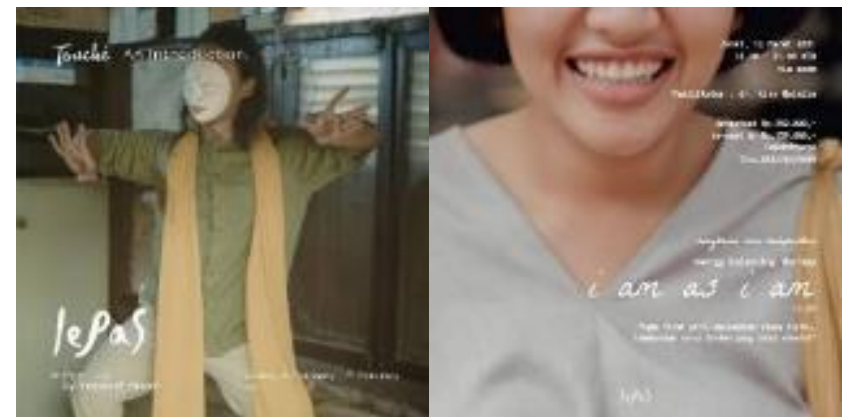

Fig. 5. Lepas Wear's Online Event ini 2021.
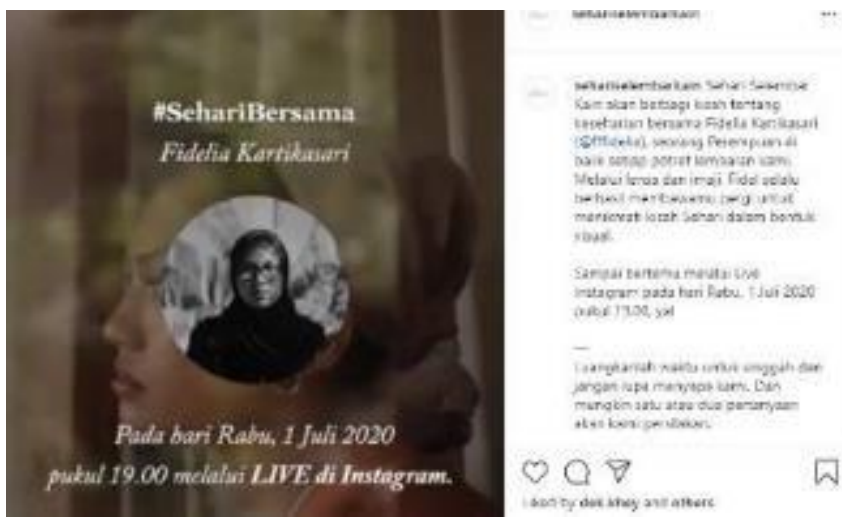

Fig. 6. Sehari Selembar Kain Event in 2020.

TABLE II: TACTICAL BRAND STORY COMPARISON

\begin{tabular}{|c|c|c|c|}
\hline $\begin{array}{l}\text { Tactical Brand } \\
\text { Story }\end{array}$ & Sewderhana Goods & Lepas Wear & Sehari Selembar Kain \\
\hline Public Relation & influencer & $\begin{array}{l}\text { influencers in the creative industry } \\
\text { figure with a specific profession. }\end{array}$ & an influencer in each product series \\
\hline $\begin{array}{l}\text { Frequency of } \\
\text { Public Relation }\end{array}$ & $\begin{array}{c}\text { randomly: } 1-3 \text { times in the last } \\
\text { two year }\end{array}$ & in every product series & $2-5$ times \\
\hline Event in 2020 & $\begin{array}{l}\text { Folkaland in 2020: collaborate } \\
\text { with fellow local brands to } \\
\text { promote bundling products } \\
\text { through some micro-influencer. }\end{array}$ & $\begin{array}{c}\text { - Offline/online as workshops or classes } \\
\text { related to mental health or self-healing. } \\
\text { - Local markets (bazaar) in } 2019 \\
\text { - Collaboration with other brands in } 2020 \\
\text { to create bundling products. } \\
\text { - 2020-2021 focus on the online event } \\
\text { due to Covid-19: bazaar and Instagram } \\
\text { live. }\end{array}$ & $\begin{array}{c}\text { - Online events such as Instagram } \\
\text { live with influencers to share } \\
\text { their stories. } \\
\text { - Brand collaboration to create } \\
\text { product bundling }\end{array}$ \\
\hline $\begin{array}{l}\text { Frequency of } \\
\text { Event }\end{array}$ & $1 \mathrm{x}$ & $>5$ & $2 \mathrm{x}$ \\
\hline $\begin{array}{l}\text { Communication } \\
\text { and Social Media } \\
\text { Content }\end{array}$ & $\begin{array}{l}\text { - Imagery: dominated in photo } \\
\text { - Tone: warm and bright } \\
\text { - Warm, poetic, and friendly in } \\
\text { Indonesian } \\
\text { - Text on photo }\end{array}$ & $\begin{array}{c}\text { - Imagery: photo and video } \\
\text { - Tone: warm and bright } \\
\text { - Warm, poetic, and friendly in } \\
\text { Indonesian } \\
\text { - Text on photo or video and graphic } \\
\text { element content. }\end{array}$ & $\begin{array}{l}\text { - Imagery: Photos and videos. } \\
\text { - Tone: warm and dark } \\
\text { - Warm, poetic, and friendly Indone } \\
\text { - Text on the photo or video and } \\
\text { graphic element content. }\end{array}$ \\
\hline Channel Mix & $\begin{array}{c}\text { Promotion: Instagram } \\
\text { Product purchase: } \\
\text { Instagram, WhatsApp, Line, } \\
\text { Tokopedia. }\end{array}$ & $\begin{array}{c}\text { Promotion: Instagram } \\
\text { Purchase: } \\
\text { Instagram, WhatsApp, website. }\end{array}$ & $\begin{array}{c}\text { Promotion: } \\
\text { Instagram. } \\
\text { Product purchase: WhatsApp, } \\
\text { Shoppe, Line, Tokopedia, and also } \\
\text { the website }\end{array}$ \\
\hline
\end{tabular}




\section{Engagement Rate}

TABLE III ENGAGEMENT RATE COMPARISON

\begin{tabular}{cccc}
\hline $\begin{array}{c}\text { Average } \\
\text { Interactions }\end{array}$ & $\begin{array}{c}\text { Sewderhana } \\
\text { Goods }\end{array}$ & Lepas Wear & $\begin{array}{c}\text { Sehari } \\
\text { Selembar Kain }\end{array}$ \\
\hline $\begin{array}{c}\text { Followers } \\
\text { Average }\end{array}$ & 1,400 & 13,000 & 4,500 \\
$\begin{array}{c}\text { Comment } \\
\text { Average Likes }\end{array}$ & 1 & 9 & 1 \\
The number of & 34 & 298 & 94 \\
$\begin{array}{c}\text { Customer Tags } \\
\text { Engagement }\end{array}$ & 33 & 360 & 126 \\
Rate & $2.5 \%$ & $2.4 \%$ & $2 \%$ \\
\hline
\end{tabular}

The measurement of engagement rate is based on comments, likes, and total followers (1). This calculation is based on the last ten posts by counting the average number of likes and comments. Sewderhana Goods, Lepas Wear, and Sehari Selembar Kain, local brands that apply storytelling techniques, have a reasonable engagement rate and engagement rate between $1 \%$ and $3.5 \%$. This can indicate a good interaction with local brand content that uses storytelling. In the digital era, the power of content greatly determines consumer interaction, with high consumer engagement can be a sign that business social media is publishing valuable content.

The engagement comparison above shows that Sewderhana Goods has good engagement with an audience size of 1,400 followers. However, the content has not succeeded in increasing followers like Lepas Wear. In addition, Sewderhana Goods content has not improved the element "involving" as a signature story element, which can be shown from Tag Instagram by consumers, and the average comments are still limited. This condition is due to the inconsistent frequency of tactical brand stories like another brand.

Sewderhana Goods has not strengthened its brand character through public relations or events because character plays an essential role in brand storytelling. This causes the signature story of Sewderhana Goods has not to be adequately conveyed to the audience.

Overall, Lepas Wear is a brand that has implemented brand storytelling well, even though it is still a new business. This is proven by the quality of the content and the fast growth of followers to get good awareness amid competition with more and more new brands.

\section{BUSINESS SOLUTION}

Based on the benchmarking results of Sewderhana Goods compared to other brands, it turns out that the Sewderhana Goods weakness is the lack of effort in promoting its brand, namely in its tactical brand story, which plays an essential role in strengthening the signature story. Here are some business solutions that can be applied to Sewderhana Goods in strengthening its brand storytelling strategy:

(1) Improve the visuals content by increasing the product experience.

(2) Involve influencers or inspiring figures in each product series or the content creation.

(3) Participate more in promotional activities or create campaigns in the product series so that consumers can interact more deeply and sustainably with the brand through collaboration. For example, collaborate with other brands to create stories with specific themes.

\section{CONCLUSION}

Along with this dynamic creative industry, a brand must continue to engage with its consumers. The branding strategy must be planned from the start. This is also reinforced by the digital marketing era, where social media content depends on audience involvement to gain awareness.

Sewderhana Goods has tried to implement brand storytelling as its marketing strategy. However, compared to brands of its age, Sewderhana Goods have not increased awareness or deeper interactions with consumers. The cause of the not optimal brand storytelling strategy at Sewderhana Goods is because the signature story elements are not yet strong, especially the empathic character elements and involve. Its promotion strategy must also strengthen the brand story through tactical brand stories. Benchmarking results show that Sewderhana Goods has not maximized the frequency of events, public relations, and strategy variations.

Today, building a brand is an essential thing for new brands. Every brand must convey its signature story well by implementing a consistent tactical brand story by paying attention to the signature story elements to recognize and have good engagement. Consistency is the essential thing in the digital era, especially in spreading the brand's story.

\section{REFERENCES}

[1] Indonesia Trip News. (2021, February 17). Tren Terhadap Brand dan Produk Lokal Terus Tumbuh. Retrieved July 25, 2021, from https://indonesiatripnews.com/ulasan-menarik/tren-terhadao-branddan-produk-lokal-terus-tumbuh/.

[2] Chiu, H. C., Hsieh, Y. C., \& Kuo, Y. C. (2012). How to Align your Brand Stories with Your Products. Journal of Retailing, 88(2), 262275. https://doi.org/10.1016/j.jretai.2012.02.001.

[3] Walter, E., \& Gioglio, J. (2018). The Laws of Brand Storytelling: Win-and Keep-Your Customers' Hearts and Minds (1st ed.). McGraw-Hill Education. $\quad$ Retrieved from https://lccn.loc.gov/2018030682.

[4] Moin, S. M. A. (2020). Brand Storytelling in the Digital Age: Theories, Practice, and Application (1st ed. 2020 ed.).

[5] Aaker, D., \& Aaker, J. L. (2016). What Are Your Signature Stories? California Management Review, 58(3), 49-65. https://doi.org/10.1525/cmr.2016.58.3.49.

[6] Aaker, D. (2018). Creating Signature Stories: Strategic Messaging that Energizes, Persuades and Inspires.

[7] Scrunch. (n.d.). What is a Good Engagement Rate on Instagram? Retrieved July 28, 2021, from https://scrunch.com/blog/what-is-agood-engagement-rate-on-instagram/.

[8] Creswell, J. W., \& Tashakkori, A. (2007). Editorial: Differing Perspectives on Mixed Methods Research. Journal of Mixed Methods Research, 1(4), 303-308. https://doi.org/10.1177/1558689807306132.

[9] Kotler, P., \& Armstrong, G. (2017). Principles of Marketing.

[10] Sammut-Bonnici, T. (2015). Benchmarking. Wiley Encyclopedia of Management, 1-2. https://doi.org/10.1002/9781118785317.weom120043.

[11] Zairi, M., \& Leonard, P. (2011). Practical Benchmarking: The Complete Guide. 
European Journal of Business and Management Research www.ejbmr.org

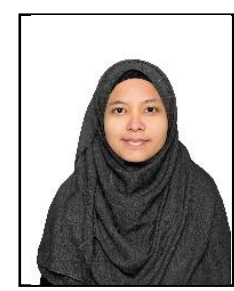

Fairuz Nisa Fauziah was born in March 28, 1995

in Mataram, Indonesia. Graduated from Urban and Regional Planning at ITENAS Bandung in 2017.

She pursued her Master degree in Master of Business Administration at Bandung Institute of Technology, Indonesia, and graduated in 2021.

She has research interests regarding branding and marketing strategy. She was currently developing her business in the fashion and creative industry.

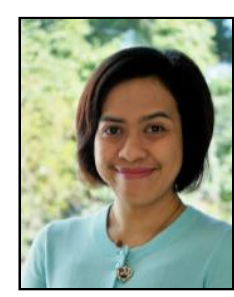

Ira Fachira is an Assistant Professor and a lecturer at the Bandung Institute of Technology (ITB). She belongs to the business strategy and marketing interest group, School of Business and Management. She started her teaching career as a tutor in SBM ITB in 2004 before becoming a lecturer in 2006. Ira Fachira was trained as a scientist in her undergraduate degree in Biology and applied engineering frameworks to gain a masters' degree in Industrial Engineering at Bandung Institute of Technology. She completed her sociology approaches for $\mathrm{PhD}$ research in marketing management at Massey University, New Zealand (Aotearoa). Her research interest is social media in marketing, and also fascinated with the relationship between popular culture, marketing, and consumer storytelling. 